\title{
CHAPTER SEVENTEEN SOCIAL INTERACTION AND VIRAL PHENOMENA
}

\author{
BEN CULLEN
}

\section{INTRODUCTION}

Recently, Gardin has written of 'the amazing convergence between the positions defended...by C.Renfrew, I.Hodder, and others, under various names (cognitive archaeology, symbolic archaeology, contextual archaeology), and the major theses which characterize the hermeneutic current in contemporary semiotics' (Gardin 1992). More archaeologists are choosing to emphasize that the symbolic and economic aspects of human existence are intimately related, and perhaps even inseparable. Examples would include discussions of the intimate relationship between religion and trade (Flannery and Marcus 1993:262), and between subjective perception and the physical landscape (Bender 1993:257). Yet, although Renfrew also hints at the possibility of a new synthesis, discussing the role of symbols in a wide range of human activities (Renfrew 1993b:249, 1994), he has been careful to qualify his remarks:

Perhaps we shall soon see some convergence between such fields as cognitive psychology, studies in artificial intelligence, computer simulation and cognitive archaeology. The time may be ripe for a great leap forward. But I don't see this happening until those archaeologists interested in the symbolic and cognitive dimensions devote more attention to the formation of a coherent, explicit and in that sense scientific methodology by which that dimension can be systematically explored through the examination and analysis of the archaeological record.

(Renfrew 1993b:250)

In light of such rumours of a new theoretical synthesis in the making, it is pertinent to consider the recent revival in Darwinian culture theory, and to consider whether any parallels may be drawn between the two philosophical trends. Ultimately, any new synthesis will need to align itself with some kind of general model of culture, humanity and cultural process. A number of candidates for this role can be found within the growing body of neo-Darwinian literature which focuses on the nature of cultural change.

There are a number of different aspects of human culture which neo-Darwinian theory (concerning the influence of selective forces on the reproductive success of independently generated variants) must ultimately address. One is the problem of the origin of the capacity for culture, which was so carefully distinguished from other issues by Rindos (1986a, b, 1989) in the 1980s. The cultural capacity must be genetically 
advantageous to its bearers in some sense, or it could never have evolved as a hominid trait.

A second and closely related problem is that of the origin of modern human culture, which may or may not be synonymous with the first. Knight (1991, and see this volume) has shown how it is conceivable that the cultural capacity might only have yielded practically oriented cultural traditions, oriented around knowledge of palpable social relations, food/shelter procurement and relatively simple artefacts such as the handaxe, for many millennia (Knight 1991:258) — cultures of practical reason. Early hominid, and non-human animal cultures are more limited than those of modern humans from the Upper Palaeolithic onwards. The collective dimension, which for Knight truly warrants the name human culture, requires not only the capacity, but the right social conditions, where co-operative interaction becomes extensive enough for the sustained reproduction of the new kinds of cultural phenomena we associate with the Upper Palaeolithic, such as art, to occur (Knight 1991:17-21).

The third problem of neo-Darwinian culture theory is that of the explanation of cultural change; all those changes which have occurred since the origin of culture. Although theories which concern the origin of the human cultural capacity, and of modern human culture, contribute immensely to our understanding of the parameters of human existence, they can never tell the whole story. We also need a neo-Darwinian metaphysic which can explain cultural change on an archaeological timescale, in addition to one which explains genetic evolution on a palaeontological timescale.

While a number of other chapters in this volume are concerned at least partly with the first two problems, this chapter is oriented toward the third: the development of an explanatory framework for cultural change. To use an alternative and more postmodernist turn of phrase, one might say that this chapter is concerned with developing a psychobiology of cultural phenomena, human agency, cultural tradition, social constraint and historical contingency. The particular kind of framework advocated is cultural virus theory (Cullen 1990, 1993a), which can be regarded as a distinctive variety of dual inheritance theory or cultural selectionism (Rindos 1986b: 315), or of evolutionary culture theory (Durham 1991). This is a rapidly growing body of literature in these traditions, both within archaeology (Dunnell 1980, 1989, Fletcher 1992, Leonard and Jones 1987, Neff 1993, O’Brien and Holland 1992, Shennan 1991), and in other disciplines (Ball 1984, Boyd and Richerson 1985, Braun 1990, Corning 1987, Dawkins 1989, Durham 1991, Heylighen 1992, Moritz 1990, Sperber 1985). Such approaches are united by the common goal of applying neo-Darwinian metaphysics to cultural change, where culture is explicitly viewed as both historically contingent, and genealogically independent of the human genome.

Cultural selectionism should be distinguished from the other main body of neoDarwinian anthropological literature, which is sometimes termed 'sociobiology'. Work in that perspective focuses on the universal, genetically emergent capacities for culture, creative decision-making, and domain-specific reasoning, and on the role that such capacities play in increasing the genetic fitness of their bearers under certain social or environmental conditions (e.g. Brown 1991, Cosmides and Tooby 1987, Freeman 1992, Hinde 1991, Lee 1991, Mithen 1990, Steele in press). Although none of these frameworks exclude the cultural domain altogether, human cultures are not explicitly 
modelled as neo-Darwinian inheritance systems in their own right. In such approaches neo-Darwinian principles are applied primarily to the understanding of the evolved structures of the human brain. This means that such approaches are most suited to explaining the kinds of phenomena which are determined by the biology of human cognition, such as the phenomena discussed by Jung, Freud, Kant or Lévi-Strauss (Miller 1993:139), and not to explaining the culturally influenced aspects of human psychology as discussed by Durkheim, Marx, Locke, Boas, Kroeber or Mead (Freeman 1992:3-6).

\section{WHY WE NEED A DARWINIAN METAPHYSIC FOR CULTURAL PROCESS}

Just as each mammalian gene pool is subject to phylogenetic constraints, which limit the range of mutations which can be produced, so must each cultural tradition place limitations on the production of new ideas which transcend that tradition. A common cultural heritage may then yield widespread distributions of cultural phenomena which are based purely in the historical contingencies of that shared cultural ancestry. Such 'universals' could easily have been otherwise; they would be the legacy of an original culture which just happened to be at the right place and the right time. Since then many new ideas may have arisen, new ideas which, by definition, transcended the cultural traditions of which they were part. But each new idea would be a thematic derivative of a pre-existing structure in the tradition from which it emerged. Such heritage constraint can be offered as a non-genetic explanation not only for 'human universals', but for all sorts of less widespread similarities between cultures which share more recent common cultural ancestors.

The variant of cultural selectionism proposed here would therefore predict that a kind of 'constrained viral phenomenon' pattern should occur in archaeological and ethnographic variation, where artefact morphology loosely and intermittently co-varies with human morphology. Such patterns are a direct corollary of the cultural selectionist notion that bones and stones are products of two independent but superimposed Darwinian systems: the spatially or socially constrained patterns of social interaction which permit genetic evolution can also channel cultural transmission. On the other hand, non-cultural selectionist Darwinian frameworks, being based on species-specific, genetically emergent universals, would predict a pattern of either total correlation, or no correlation at all.

There is a growing body of archaeological and anthropological literature which relates this ubiquitous pattern of cultural tradition to a fundamentally selective process (cf. Cullen 1993b: Chapter 8, for an extensive review). Fletcher (1992) and Shennan (1991), for example, have discussed the implications of cultural tradition or heritage for selective explanatory frameworks. Moreover Renfrew (1993a, 1994) has published extensively on the problem of reconciling large-scale geographic patterns in archaeology, language and genetics. Since descent-with-modification patterns are widely recognized to occur in the linguistic and genetic systems, any correlation would imply that a descent-withmodification pattern also occurs in the archaeological record. Renfrew's analysis identifies a number of ways in which genetic and cultural inheritance can either correlate 
with each other or become decoupled (for example, 1994:106), which in turn suggests a temperamental and historically contingent association between the three kinds of data. The potential independence of cultural traditions from factors relating to genetic relatedness in populations, coupled with their potential for periodic strong correlation, would suggest a cultural selectionist rather than universalist interpretation of correlations between material cultural change and genetic change in modern human social systems.

Cultural selectionist interpretations of the nature of cultural tradition may also be found in anthropology Knight (1991) has identified common elements of modern cultures which he sees as a result of the purely cultural descent of modern myths from prototypes in the Upper Palaeolithic. And, finally, anthropologists such as Cavalli-Sforza (1991) and Durham (1991) have explicitly described cultural data as the products of a Darwinian inheritance system which exhibits an intermittent rather than comprehensive correlation with genetic inheritance. If archaeological and ethnographic variation does display a pattern of descent with modification, but one which, at best, only exhibits a partial or intermittent correspondence with variation in biological traits, then it would seem to follow that archaeology needs a cultural selectionist approach of some sort.

\section{SOCIAL INTERACTION AND THE SPREAD OF CULTURAL PHENOMENA}

As mentioned briefly above, Knight (1991:17-21, 258, and this volume) has argued that human culture as we know it may have required more than the mere existence of the human capacity for culture to be brought into being. For Knight, extensive social interaction is itself an additional necessary condition, which in turn implies a social structure capable of facilitating a high rate of social interaction. Although apes have the genetic ability to acquire a variety of cultural phenomena in the context of intense social interaction in modern human communities, Knight questions whether ape societies or Early and Middle Palaeolithic hominid/ human societies would often have yielded the extensive social networks of Homo sapiens sapiens. Only much later, at the end of the Middle Palaeolithic, did social conditions enable the sustained reproductive success of the new kinds of ideas, behaviour patterns and artefacts (such as art, and the elaboration of ritual) which characterize Upper Palaeolithic and more recent cultural assemblages:

Memes had to be able to circulate freely over vast areas. Only this could guarantee that they did not die out with the extinction of particular local populations... The late Neanderthals in each inhabited European district seem to have been in principle capable of almost any symbolic invention. But each of their most unexpectedly 'modern'-seeming artistic or other advances - many of which Marshack (1989) has beautifully documented for us-seems to have occurred only in a localised way, usually disappearing in the place of its origin before it could become part of the cultural heritage of the Neanderthals as such. This was the Neanderthals' handicap.

(Knight 1991:269)

This decoupling of the evolution of the cultural capacity and the appearance of 
sophisticated cultural phenomena can be visualized via the metaphor of a forest, a metaphor which I call 'the jungle of human sentiment'. A forest is a potentially continuous ecological assemblage, composed of many different populations of organisms in a kaleidoscope of symbiotic, predatory and parasitic relationships.

Within this general ecological assemblage, the tree may be viewed as a convenient representation of the development and differentiation of a human phenotype with a fully developed capacity for culture, from seed to towering giant. The form taken by each phenotype is highly dependent upon environmental factors such as light, climate, nutrition and interaction with other trees, just as the human phenotype is affected by developmental conditions in the manner discussed by Ingold (1986, 1990, 1991, 1993). The extent of social interaction can be visually represented in terms of the closeness of the trees and the degree to which their branches interlock to form a canopy. Cultural phenomena are represented in the form of the various animals and plants which inhabit the canopy. Together, the phenotypes of the trees provide a convoluted and highly structured living landscape, representing the genetically emergent phenomena of the brains of a human community.

Any decoupling of the individual capacity for culture and the explosion of certain kinds of cultural phenomena in the Upper Palaeolithic can be represented in terms of the degree to which fully evolved trees are grouped together in such a way as to provide an interlocking canopy. At one point, trees, as such, evolve, and represent individual hominid phenotypes with a fully developed capacity for culture. However, as long as each tree stands alone, like a tree in a savannah environment, specialized arboreal fauna - being unable to survive by moving from tree to tree-will die when the tree dies. Many intermediate states between savannah and woodland can then represent correspondingly intermediate states in the extent of social interaction and in the cohesion of the networks thereby created. An open woodland with a loose, intermittent canopy of interlocking branches, for example, might be a suitable metaphor for the degree of social interaction involved in Neanderthal social networks, while much of the earlier Palaeolithic could well have involved contingent oscillation between open woodland and the social interaction equivalent of tree-dotted savannah. Phenomena such as handaxes could still survive indefinitely through parent to child enculturation.

Thus, if Knight's hypothesis is to be pursued within the metaphor, we may suggest that the habitat or niche to which cultural phenomena are adapted (communities of hominids with a fully developed cultural capacity) was unevenly distributed and highly unreliable throughout most of the Lower and Middle Palaeolithic. When new ideas appeared in one community there may have been very few opportunities for that idea to have been taught to individuals of other communities some distance away. Under such circumstances, a cultural phenomenon which had a negative effect on the genetic reproductive success of human individuals would be unlikely to survive for long, quickly plunging the small group to which it belonged and itself into extinction. The relationship between human and artefact would have tended to evolve toward stable, symbiotic, ecological relationships, which are perhaps indicated by the long associations between Homo erectus and Acheulian assemblages, and between archaic Homo sapiens and Mousterian assemblages. The long-term survival of the distinctive cultural phenomena which characterize Upper Palaeolithic and later assemblages would, I propose, have required the 
existence of extensive coalitions between people distributed over a wide area, and maintained through a continuous fabric of social interaction. Such coalitions would involve, among other things, a fully developed capacity for language; societies where 'verbal grooming' (Aiello and Dunbar 1993) had become the primary means of maintaining large numbers of ongoing relationships, and an indispensable medium for the education of apprentices and novices.

\section{CULTURALLY REPRODUCED ENTITIES AS VIRAL PHENOMENA}

I have used the 'forest' metaphor to make the point that even given a capacity for cultural learning, cultural phenomena still survive only while their human 'hosts' remain extensively networked into widespread social communities. However, my preferred metaphor for the intrinsic dynamic of cultural evolution is that of the virus. There are a number of reasons why the general category of viral phenomena provides a better starting point for representing cultural traditions in Darwinian terms, than the more familiar kinds of organisms such as parasites. First, despite the fact that they have elaborate mechanisms for concealing themselves within the human body (Paul 1993), 'fully organismic' parasites never actually become part of their hosts. Viruses, on the other hand, inject naked hereditary material into human cells (Greene 1993:69): in the case of retroviruses, that genetic material can then insert itself into a human chromosome (Kuby 1992:463466). At certain stages of their existence the distinction between viral phenomenon and host becomes very confusing indeed. Despite this blurring effect, microbial viruses are still classified according to their phylogenetic relationships independently of the taxa to which their hosts belong (Postgate 1989). The concept of a viral phenomenon is therefore convenient in that it implies periodic episodes of integration into host minds and genealogical independence from host cells. Knowledge, once learned, can be viewed as physically existing within the brain as a body of altered neuronal structures (Cullen 1993b: Chapter 9, cf. Delius 1991, Edelman 1989, 1992, Levine 1988). But the virus analogy also allows cultural phenomena to be classified phylogenetically, according to cultural tradition, independently of human or hominid phylogeny.

Another advantage of the concept of viral phenomena is that cultural entities and microbial viruses share the potential for separation of hereditary material from phenotype, a quality which true organisms do not possess. In the process of parasitizing a cell, the non-genetic parts of the virus, its phenotype, are left attached to the cell membrane (Greene 1993:69), while its hereditary material enters the interior of the host cell. Similarly, the phenotype of a cultural phenomenon, the manufacturing behaviour and the artefact itself, are separated from their hereditary material, the manufacturing knowledge residing in human minds. There are many additional qualities which support the joint inclusion of viruses and cultural phenomena in a general category of viral phenomena, as 'sub-organismic' biological individuals. Such qualities include a lack of any intrinsic metabolism or life process (despite the protests of some virologists, Slap 1991), and the lack of the ability to self-reproduce without the help of some proximate reproductive agency. There are also a number of reasons why a cultural entity is better viewed as a viral phenomenon than as a trait: cultural phenomena display genealogical 
independence from genetically emergent traits, and the geographic distribution of a population of cultural phenomena need not be anywhere near as extensive as the geographic distribution of the human population within which it is found.

\section{THE DOMESTIC BEHEMOTH}

The chapters in this volume focus on the evolution of hominid social systems, and the appearance in the archaeological record of cultural traditions and of modern human societies. As I indicated earlier, my concern here is to develop an informal verbal model of cultural selection dynamics; and in view of my contention that social systems facilitating rapid cultural evolution only appeared in the Upper Palaeolithic, I shall restrict illustrations of the model to an illustrative reinterpretation of a familiar instance of cultural evolution in modern human populations for whom a good material record exists. Thus in the space that remains I would like to present a brief outline of how one of the most commonly referred to kinds of prehistoric artefact, the megalithic phenomena of the European archaeological record, may be viewed as a class of viral phenomena surviving in a psychological environment made up both of other cultural phenomena and of genetically emergent psychological factors. The aim is to translate the general principles of cultural virus theory into a more familiar set of archaeological categories. Axiomatic to my interpretation is the assumption that megalith-builders inhabited social systems of the requisite level of complexity for cultural phenomena to be propagated through an extensive and frequent pattern of social interactions.

In cultural virus theory each megalithic tomb or stone circle of the European Neolithic would be viewed as an instance of a megalithic phenotype, the physical product of a body of knowledge about the techniques of megalith-making. This knowledge is the hereditary material of the megalithic tradition, the basic megalithic 'thing' whose primary 'goal' is to get reproduced by bringing new apprentices to the megalith-building trade. As I have suggested, knowledge, once learned, can be viewed as physically existing within the brain as a body of altered neuronal structures. Like a retrovirus which has been reversetranscribed, knowledge of a particular cultural production process like megalith-building is lost amongst a vast assemblage of other neuronal structures inside the mind of its host, except when it is being used to make megalithic artefacts, or being taught to an apprentice megalith-maker. Megalith-manufacturing behaviour patterns are also part of the phenotype of this knowledge. The megalithic viral phenomenon, then, is a threetiered phenomenon consisting of manufacturing knowledge, manufacturing behaviour and the megaliths themselves.

The above constitutes a brief outline of what megalithic phenomena are in cultural virus theory. What was their relationship to the contexts in which they are found, and how did that relationship affect their continued survival as a living tradition within Neolithic society? One important thing to bear in mind in interpreting the 'cultural virus theory' approach to context, is that megalith is to brain as virus is to cell: cultural phenomena are found in ecological relationships with individual humans or social groups, whereas microbial viruses parasitize individual cells rather than whole organisms. Moreover, just as in the case of human microbial viruses (Mitchison 1993:105), the 
relationship between megalithic phenomena and the Neolithic communities in which they are found could have varied all the way from beneficial to harmful. Which strategy emerged at any particular time would have been highly contingent and could have varied from century to century, or even from decade to decade, throughout the Neolithic.

In 'cultural virus theory' a large number of knowledge-behaviour-artefact combinations are domestic viral phenomena - that is, they are maintained and reproduced actively and deliberately, either by the whole community, or by some specialist group of individuals. Given the great amount of organized labour, however unskilled, involved in the building of megalithic phenomena (Sherratt 1990:147), it would be ridiculous to consider their manufacture as anything other than active and deliberate. In terms of the possible ways in which such cultural viruses may propagate themselves they are, therefore, ecologically equivalent to domesticated animals and plants in terms of the adaptive strategies available to them. However, this is not to say that megalithic phenomena were always symbiotic or genetically beneficial to the people who manufactured them. It is perfectly conceivable that a group of people might continue in a lifestyle based around one or more domesticated animal or plant species long after the emotional and economic costs have come to outweigh the benefits, particularly if the imbalance of cost and benefit is for some reason difficult to calculate. Such may have been the case, from time to time, with the human activity associated with the building and maintenance of megalithic phenomena. For a domesticate, parasitic ecological relationships emerge through the subjective assessment of the value of that domesticate, whereby people are simply not able to 'see the cost' involved in its support. This allows the cost, in terms of the genetic reproductive success of megalith builders and their kin, to fluctuate through time without making any immediate impact upon the cultural fitness of megaliths.

Even active human agents in charge of their own destiny will not automatically make 'genetically correct' choices to maximize their inclusive fitness: rather, they will make those choices which seem to them to be the best at the time, subjective choices which could be termed 'culturally correct' and 'individually correct'. An assemblage of megalithic phenomena, like a herd of domesticates, cannot be maintained unless individual actors choose to do so. But since all choices are informed by the values, morals and measurements of one or more cultural traditions, it is highly unlikely that any given choice which (by definition) must be correct in terms of the culturally and experientially informed judgements of individuals, will also be the best in genetic terms. Every cultural tradition can be expected to produce characteristic 'distortions' of the value of different human activities and artefacts, since systems of evaluation are themselves cultural phenomena. Such distortions need not be catastrophic or genetically suicidal, only small and persistent. Through their inherent dependency on value-laden assessment of the importance of artefacts, people become vulnerable to the possibility of passive exploitation by overvalued cultural phenomena. Other artefacts, which involve less genetic cost to their manufacturers, may simply not hold the same fascination, the same 'magic', the same aesthetic charisma, within the various culturally specific and historically contingent world views of the European Neolithic.

All evidence would seem to suggest that megalithic phenomena were extremely well adapted to Neolithic states of mind: their appeal was the sum of a long list of positive and 
mutually supportive connotations. They had an initial similarity to the dwellings of some communities of the period, as discussed by Sherratt (in press) and Hodder $(1985,1990$, in press), which also constitute a likely cultural ancestor for the megaliths themselves. At a time when so many cultural categories, anxieties and aspirations revolved around images of domestication and its contrast with the wild (Hodder 1990), houses, as artefacts, were preadapted to a new cognitive niche as tombs and monuments. A series of innovations produced new 'megalithic' versions of the houses, which fitted the new symbolic niches of the tomb even better than the houses themselves. The subsequent elaborations of various aspects of megalithic phenomena, such as various forms of art, the association with the additional domesticating imagery of the axe (Hodder in press, Thomas and Tilley in press) and the possible use of narcotics, could only have enhanced their contextual 'charisma' even further. Before very long, megalithic phenomena must have become an indispensable part of the cultural ecology of Neolithic communities.

\section{CONCLUSION}

In the last decade, neo-Darwinian theory has often been thought to be incompatible with a variety of interrelated aspects of the postmodernist inspired interpretive archaeology, such as notions of the active, self-determining individual (Hodder 1985:1, Shanks and Tilley 1987a:56, 1987b:175), of the influence of society on such individuals (Shanks and Tilley 1987b:177), of cultural tradition and historical contingency (Thomas 1991b:15, Shanks and Tilley 1987b:176), and of active material culture and contextual interpretation (Hodder 1991, 1992:12-14, in press, Barrett 1987:10, 1990:179, Thomas 1991a, 1991b:17, in press, Thomas and Tilley, in press). Such opinions are an understandable result of the fact that the explanatory frameworks against which they reacted, like much of Darwinian anthropology and indeed sociobiology in general, ignored interpretive factors, being based around pan-human, genetically emergent human capacities and their role in promoting human reproductive success. In this chapter an attempt has been made to outline an alternative Darwinian perspective, cultural virus theory, which has been able to accommodate postmodernist principles by viewing artefacts as cultural organisms adapting in such a way as to take advantage of human agency in a particular cultural context.

\section{ACKNOWLEDGEMENTS}

I would like to thank Ian Hodder, Colin Renfrew, Andrew Sherratt and Julian Thomas for kindly sending me unpublished manuscripts.

\section{REFERENCES}

Aiello, L.C. and Dunbar, R.I.M. (1993) 'Neocortex size, group size, and the evolution of language.' Current Anthropology 34:184-193.

Ball, J.A. (1984) 'Memes as replicators.' Ethology and Sociobiology 5:145-161. 
Barrett, J.C. (1987) 'Fields of discourse.' Critique of Anthropology 7:5-16.

Barrett, J.C. (1990) 'The monumentality of death: the character of Early Bronze Age mortuary mounds in southern Britain.' World Archaeology 22:179-189.

Bender, B. (1993) 'Cognitive archaeology and cultural materialism.' Cambridge Archaeological Journal 3:257-260.

Boyd, R. and Richerson, P.J. (1985) Culture and the Evolutionary Process. Chicago: University of Chicago Press.

Braun, D.P. (1990) 'Selection and evolution in nonhierarchical organization.' In S.Upham (ed.) The Evolution of Political Systems, pp. 63-86. Cambridge: Cambridge University Press.

Brown, D. (1991) Human Universals. New York: McGraw-Hill.

Cavalli-Sforza, L.L. (1991) 'Genes, people and languages.' Scientific American 265: 7278.

Corning, P.A. (1987) 'Evolution and political control: a synopsis of a general theory of politics.' In M.Schmidt and F.M.Wuketits (eds) Evolutionary Theory in Social Science, pp. 127-170. Lancaster: Reidel.

Cosmides, L. and Tooby, J. (1987) 'From evolution to behaviour: evolutionary psychology as the missing link.' In J.Dupre (ed.) The Latest on the Best: Essays on Evolution and Optimality, pp. 277-306. Cambridge, MA: MIT Press.

Cullen, B.R.S. (1990) 'Darwinian views of history: Betzig's virile psychopath versus the cultural virus.' Crosscurrents 4:61-68.

Cullen, B.R.S. (1993a) 'The Darwinian resurgence and the cultural virus critique.' Cambridge Archaeological Journal 3:179-202.

Cullen, B.R.S. (1993b) 'The cultural virus'. PhD thesis, Prehistoric and Historical Archaeology, University of Sydney.

Dawkins, R. (1989) The Selfish Gene, 2nd edn. Oxford: Oxford University Press.

Delius, J.D. (1991) 'The nature of culture.' In M.S.Dawkins, T.R.Halliday and

R.Dawkins (eds) The Tinbergen Legacy, pp. 75-99. London: Chapman and Hall.

Dunnell, R.C. (1980) 'Evolutionary theory and archaeology.' Advances in Archaeological Method and Theory 3:38-99.

Dunnell, R.C. (1989) 'Aspects of the application of evolutionary theory in archaeology.' In C.C.Lamberg-Karlovsky (ed.) Archaeological Thought in America, pp. 35-49. Cambridge: Cambridge University Press.

Durham, W.H. (1991) Coevolution: Genes, Culture, and Human Diversity. Stanford, CA: Stanford University Press.

Edelman, G.M. (1989) Neural Darwinism: The Theory of Neuronal Group Selection. Oxford: Oxford University Press.

Edelman, G.M. (1992) Bright Air, Brilliant Fire. London: Allen Lane, The Penguin Press.

Flannery, K.V. and Marcus, J. (1993) 'Cognitive archaeology.' Cambridge Archaeological Journal 3:260-267.

Fletcher, R.J. (1992) 'Time perspectivism, Annales, and the potential of archaeology.' In A.B.Knapp (ed.) Archaeology, Annales, and Ethnohistory, pp. 35-49. Cambridge: Cambridge University Press.

Freeman, D. (1992) Paradigms in Collision: The Far-reaching Controversy over the Samoan Researches of Margaret Mead and its Significance for the Human Sciences. Research School of Pacific Studies, The Australian National University.

Gardin, J.C. (1992) 'Semiotic trends in archaeology.' In J.C.Gardin and C.S. Peebles (eds) Representations in Archaeology. Bloomington and Indianapolis: Indiana 
University Press.

Greene, W.C. (1993) 'Aids and the immune system.' Scientific American 269: 66-73.

Heylighen, F. (1992) "“Selfish" memes and the evolution of co-operation.' Journal of Ideas 2:77-84.

Hinde, R.A. (1991) 'A biologist looks at anthropology.' Man (n.s.) 26:583-608.

Hodder, I. (1985) 'Post-processual archaeology.' Advances in Archaeological Method and Theory 8:1-25.

Hodder, I. (1990) The Domestication of Europe: Structure and Contingency in Neolithic Societies. Oxford: Basil Blackwell.

Hodder, I. (1991) 'Interpretive archaeology and its role.' American Antiquity 56: 7-18.

Hodder, I. (1992) 'Symbolism, meaning and context.' In I.Hodder (ed.) Theory and

Practice in Archaeology, pp. 11-23. London: Routledge.

Hodder, I. (in press) 'Megaliths: production and reproduction.' Ms.

Ingold, T. (1986) Evolution and Social Life. Cambridge: Cambridge University Press.

Ingold, T. (1990) 'An anthropologist looks at biology.' Man (n.s.) 25:208-228.

Ingold, T. (1991) 'Comment on "Biology and behaviour in human evolution".'

Cambridge Archaeological Journal 1:219-221.

Ingold, T. (1993) 'Comment: on "The Darwinian resurgence and the cultural virus critique".' Cambridge Archaeological Journal 3:194-195.

Knight, C. (1991) Blood Relations: Menstruation and the Origins of Culture. New Haven and London: Yale University Press.

Kuby, J. (1992) Immunology. New York: W.H.Freeman.

Lee, P.C. (1991) 'Biology and behaviour in human evolution.' Cambridge Archaeological Journal 1:207-226.

Leonard, R.P. and Jones, G.T. (1987) 'Elements of an inclusive evolutionary model for archaeology.' Journal of Anthropological Archaeology 6:199-219.

Levine, D.S. (1988) 'Survival of the synapses.' The Sciences 28:46-52.

Miller, J. (1993) The Passion of Michel Foucault. London: Harper/Collins.

Mitchison, A. (1993) 'Will we survive?' Scientific American 269:102-108.

Mithen, S. (1990) Thoughtful Foragers: A Study of Prehistoric Decision-Making.

Cambridge: Cambridge University Press.

Moritz, E. (1990) 'Memetic science: I-general introduction.' Journal of Ideas 1: 1-23.

Neff, H. (1993) 'Theory, sampling, and analytical techniques in the archaeological study of prehistoric ceramics.' American Antiquity 58:23-44.

O'Brien, M.J. and Holland, T.D. (1992) 'The role of adaptation in archaeological explanation.' American Antiquity 57:36-59.

Paul, W.E. (1993) 'Infectious diseases and the immune system.' Scientific American 269:56-65.

Postgate, J. (1989) 'Microbial happy families.' New Scientist 21 January: 40-44.

Renfrew, C. (1993a) The Roots of Ethnicity. Archaeology, Genetics and the Origins of Europe. Rome: Unione Internationale Degli Instituti di Archeologia Storia e Storia Dell'arte in Roma.

Renfrew, C. (1993b) 'Cognitive archaeology: some thoughts on the archaeology of thought.' Cambridge Archaeological Journal 3:248-250.

Renfrew, C. (1994) 'Explaining world linguistic diversity: towards a new synthesis.' Scientific American 270 (January): 104-112.

Rindos, D. (1986a) 'The genetics of cultural anthropology: toward a genetic model of the origin of the capacity for culture.' Journal of Anthropological Archaeology 5:1-38.

Rindos, D. (1986b) 'The evolution of the capacity for culture: sociobiology, structuralism 
and cultural selectionism.' Current Anthropology 27:315-331.

Rindos, D. (1989) 'Undirected variation and the Darwinian explanation of cultural change.' Archaeological Method and Theory 1:1-48.

Shanks, M. and Tilley, C. (1987a) Reconstructing Archaeology: Theory and Practice. Cambridge: Cambridge University Press.

Shanks, M. and Tilley, C. (1987b) Social Theory and Archaeology. Cambridge: Polity Press.

Shennan, S. (1991) 'Tradition, rationality and cultural transmission.' In R.W. Preucel (ed.) Processual and Postprocessual Archaeologies, pp. 197-208. Center for Archaeological Investigations, Occasional Paper No. 10. Southern Illinois University.

Sherratt, A.G. (1990) 'The genesis of megaliths: monumentality, ethnicity, and social complexity in Neolithic North-West Europe.' World Archaeology 22: 147-167.

Sherratt, A.G. (in press) 'Instruments of conversion? The role of megaliths in the mesolithic/neolithic transition in North West Europe.' In K.von Welck (ed.) Comparative Studies of Megalithics: Progress Reports and Ethnoarchaeological Approaches. Proceedings of the International Symposium, pp. 1-13. Mannheim: ReissMuseum, Museum for Archaeologie and Volkerkunde.

Slap, J.K. (1991) 'Virile viruses.' Australian Natural History 23:668.

Sperber, D. (1985) 'Anthropology and psychology: towards an epidemiology of representations.' Man (n.s.) 20:73-89.

Steele, J. (in press) 'Weak modularity and the evolution of human social behaviour.' In H.Maschner (ed.) Darwinian Archaeologies. New York: Plenum.

Thomas, J. (1991a) Rethinking the Neolithic. Cambridge: Cambridge University Press.

Thomas, J. (1991b) 'The hollow men? A reply to Steven Mithen.' Proceedings of the Prehistoric Society 57:15-20.

Thomas, J. (in press) 'The hermeneutics of megalithic space.' In C.Tilley (ed.) Interpretive Archaeologies. London: Berg.

Thomas, J. and Tilley, C. (in press) 'The axe and the torso: symbolic structures in the Neolithic of Brittany.' In C.Tilley (ed.) Interpretive Archaeologies. London: Berg. 